\title{
A Feasibility Study on the Application of Flipped Classroom Teaching Mode in College English Teaching
}

\author{
Yang Yunqing \\ Chengdu Neusoft University, Chengdu, Sichuan Province, 611844
}

Keywords: colleges and universities; English teaching; flipped classroom; teaching mode; feasibility

\begin{abstract}
In recent years, English teaching in colleges and universities has been innovating teaching mode under the requirement of new curriculum reform, and English teachers try to adjust their teaching ideas with the time, among which, the new teaching mode of flipped classroom has achieved good teaching effect. Under the guidance of this mode, college students' enthusiasm of English learning has been vastly stimulated and their English application ability is greatly improved. Meanwhile, the efficiency of English teaching has been gradually improved, which is of great significance to the deepening of teaching reform in colleges and universities. This paper briefly introduces the flipped classroom, then summarizes the current situation of English teaching in colleges and universities, and finally focuses on the feasibility of flipped classroom teaching mode, so as to provide teaching experience for English teachers.
\end{abstract}

\section{Introduction}

With the gradual improvement of China's international status, and the increasing frequency of cultural exchanges between China and other countries, English is becoming more and more important as an international language.As the base of English language learning, colleges and universities should innovate English teaching mode appropriately and learn from advanced teaching methods, which plays an important role in the cultivation of excellent English talents, and it is also the basic way to promote the benign development of our country.It can be seen that this thesis has some exploratory significance and education significance, and the feasibility analysis of flipped classroom teaching mode is as follows.

\section{Brief Introduction to Flipped Classroom}

The flipped classroom refers to the adjustment of traditional classroom teaching mode, using computer technology to complete theoretical knowledge transfer and basic knowledge consolidation, attaching great importance to the full use of classroom and after-school teaching time. The flipped classroom teaching model was first produced in the United States, and it was also known as the inverted classroom in the beginning. Later, this teaching mode was widely promoted and practiced, and the teaching effect was achieved. The pressure of teachers and students to teach and learn gradually decreased, and the anxiety and quality of teaching and learning corresponded to the improvement. At present, our country is in the mode of development and practical phase, and the application of this new model of teaching is introduced as follows ${ }^{[1]}$.

First, the principle of autonomous learning. Students should have a strong self-learning ability when using this model to learn English knowledge. Students should maintain a positive learning attitude and active participation spirit, so as to elevate the status of the subject, and then the advantages of the new teaching mode will be highlighted. Only by adhering to this principle, can this process become the process of improving students' English learning ability. Second, the task-driven principle. The English discipline requires learners to change their thinking and understand the context, so that students should practice more frequently until they form language thinking. So, English teachers make full preparations with multimedia equipment before class, carefully design teaching courseware and video, so as to ensure students learn tasks and summarize 
English problems by watching video. Then, the students will master English learning skills after the illustration of the teacher and gradually improve their language ability. Finally, the principle of reflection. Before class, students will summarize the new knowledge by watching video in English, and ask questions in class. After class, they will summarize and think about the knowledge and English problems, so as to pave the way for the following English study.

\section{Current Situation of College English Teaching}

The main reason why college English teaching is not satisfactory is that the teacher fails to arrange the teaching contents according to the actual learning situation of the students. The teacher does not pay attention to the relation between each unit, and still uses traditional teaching form to explain the basic knowledge such as word, grammar. Teachers carry out knowledge transfer in a single course, and do not attach importance to extracurricular reference. Therefore, English students' vision cannot be expanded, and their theoretical knowledge reserve is too scarce. Finally, the flipped classroom teaching mode will be restricted.

At present, most college students are accustomed to passive learning, that is, students finish their study tasks according to the arrangement of teachers, and teachers play an absolute leading role in English teaching. In the long run, students' initiative will gradually decrease, and teachers' English teaching pressure will increase correspondingly. The students' performance in the traditional teaching mode is opposite to that of the flipped classroom teaching mode. The flip class pattern requires that students have more initiative and mobility, which is a good for the quick entering into the required study state of students.

The English teacher is affected by the exam-oriented education, and in order to finish the course in the allotted time, they usually spend most of the class time teaching theoretical knowledge. Comparatively speaking, students have little time to practice their oral English and practice writing. In the long run, the student body will be entirely under the leadership of an English teacher, which will have a detrimental effect on the student's English thinking, and the student's English skills will decline. The use efficiency of classroom time directly affects the teaching effect, therefore, English teachers should make reasonable arrangement of classroom time, strive to find a balance and do well in theoretical knowledge teaching and in-class practice, and adjust their work in class reasonably.

\section{Feasibility Analysis of Flipped Classroom Teaching Mode}

The flipped classroom teaching mode is on the premise of establishing the network learning platform, and guides the English teachers to do sufficient teaching preparation, and the students to take the initiative to participate in English learning. The specific advantages of this teaching model are as follows. Firstly, it advocates the innovation of traditional teaching method. This teaching mode stresses the interaction between teachers and students, so as to improve the student body position as the goal. At the same time, it guides students to have effective absorption of the learned English knowledge. Secondly, teachers can find their own position accurately, and teachers will set their own position in the guide, and set up English problems and arrange learning tasks from the perspective of students. Teachers allocate class time reasonably. By forming a learning group to carry out English exploration activities, this will improve students' English learning ability and application level. Thirdly, in the application of flipped classroom teaching mode, students can communicate with teachers actively. Even after class, or in holidays, they can communicate in English through WeChat, QQ and other software. Teachers can respond in time, which can improve the efficiency of English learning and facilitate good practice. Fourthly, due to the differences in English foundation, English comprehension ability and learning ability of college students, flipped classroom teaching mode can apply the teaching method to students' specific guidance based on respect for students' differences. This not only saves teaching time, but also improves students' English performance and the quality of English teaching.

Nowadays, college English teachers have a higher education level, and a relatively low age 
structure. These teachers have a better understanding and practical ability of new things, and the application of flipped classroom teaching mode is more feasible. Moreover, this model can give full play to teaching advantages and highlight teaching value under the application of English teachers. The process of the application of new teaching mode is the process of the improvement of teachers' teaching ability and the accumulation of teaching experience. This mode takes computer technology as the carrier, therefore, teachers should be proficient in multimedia equipment and master the application skills of multimedia equipment. The combination of multimedia equipment and English teaching materials will greatly improve its utilization in the classroom. During this period, the level of courseware production of English teachers will be improved correspondingly. From the perspective of English teachers, this teaching model is feasible.

At present, students in colleges and universities have a strong sense of solidarity with new things, and students are more receptive new things. In the age of Internet information technology, students are well adapted to advanced technology. The flipped classroom teaching model introduced in this paper is a product of information technology. The introduction of it into English class can attract students' attention and stimulate students' enthusiasm for learning. Students are able to take the initiative to obtain the required learning resources, such as downloading English songs and searching English speech video, which means that Students can improve their English ability according to their learning needs, and make up for the lack of English. As we can see from the discussion above, the teaching mode is feasible in English classroom.

The flipped classroom teaching mode is supported by the network and the information technology. During the practical application of this mode, high standards are put forward for hardware devices. Only by providing the standard hardware facilities and hardware construction work can the application of this teaching mode be provided. At present, the information construction of colleges and universities has made good progress, and the campus network is widely spread, and the network security work is conducted in an orderly manner. At the same time, each student in the university can guarantee an electronic device. And the university has set up the electronic reading room, which can lay the hardware foundation for the application of the teaching mode ${ }^{[3]}$.

English teachers should pay attention to relevant matters when applying the flipped classroom teacher mode, which is to ensure the richness and accuracy of teaching contents. Teachers should make sure the courseware is easy to understand; and guarantee the reasonable control of multimedia video time. Specific design teaching activities are required for English teaching.

\section{Conclusion}

To sum up, with the continuous improvement of the quality education reform activity in college English major, English teachers should innovate their own teaching mode in a timely manner and adjust teaching methods in an orderly way, which not only reduces the teaching pressure, but also completes the English teaching task within the stipulated time, so as to promote the comprehensive improvement of English comprehensive ability of students. The teaching mode of flipped classroom can be infiltrated into English classroom, which can ensure students' English practice ability to be exercised, and this teaching mode meets the needs of English teaching at present stage. The English talents cultivated by this teaching mode can highlight the advantages in the international cultural exchange of China, which is conducive to the smooth progress of the reform of Chinese universities and the improvement of national comprehensive strength.

\section{References}

[1] Yang Youtao. "Feasibility Analysis of the Application of Flipped Classroom Teaching in College English Listening and Speaking” [J]. Neijiang Technology, 2013,38(04):148+105.

[2] Wang Wei. "The Feasibility of Flipped Classroom Teaching Mode in Foreign Language Teaching in Private Colleges” [J]. Modern Profession Education, 2016, (33): 27. 
[3] You Jia. “The Feasibility of Applying Flipped Classroom Teaching Mode in College English Teaching” [J]. Journal of Shanxi Coal Management Cadre Institute, 2016, 29(03): 111-112+115. 